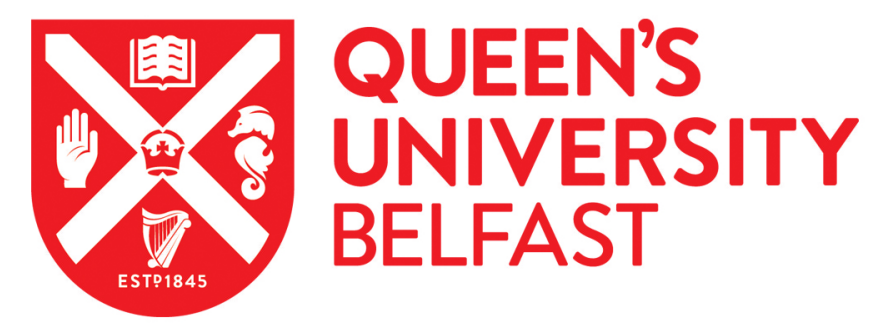

\title{
The (not so) Surprising Longevity of Identity Politics: Contemporary Challenges of the State-Society Compact in Central Eastern Europe
}

Agarin, T. (2020). The (not so) Surprising Longevity of Identity Politics: Contemporary Challenges of the StateSociety Compact in Central Eastern Europe. East European Politics, 36(2).

https://doi.org/10.1080/21599165.2020.1714598

Published in:

East European Politics

Document Version:

Peer reviewed version

Queen's University Belfast - Research Portal:

Link to publication record in Queen's University Belfast Research Portal

Publisher rights

(c) 2020 Informa UK Limited, trading as Taylor \& Francis Group. This work is made available online in accordance with the publisher's policies. Please refer to any applicable terms of use of the publisher.

\section{General rights}

Copyright for the publications made accessible via the Queen's University Belfast Research Portal is retained by the author(s) and / or other copyright owners and it is a condition of accessing these publications that users recognise and abide by the legal requirements associated with these rights.

Take down policy

The Research Portal is Queen's institutional repository that provides access to Queen's research output. Every effort has been made to ensure that content in the Research Portal does not infringe any person's rights, or applicable UK laws. If you discover content in the Research Portal that you believe breaches copyright or violates any law, please contact openaccess@qub.ac.uk. 


\title{
The (not so) Surprising Longevity of Identity Politics:
}

\section{Contemporary Challenges of the State-Society Compact in Central Eastern Europe}

\author{
Timofey Agarin \\ Queen's University Belfast*
}

\begin{abstract}
The EU accession marked the end of postcommunist institutional transition, yet the nature of relations between state institutions with their societies was far from settled. The article argues that across the East European region continuous uncertainty about the nature of the state-society compact was central to maintaining the relevance of identity in politics. This compact is best understood from the distinct perspective on who owns the state and who benefits from the current form of the state. Since, postcommunist nation-state-building was as much about the exclusion of some groups of residents from the political community as it was about limiting states' reliance on thick political ideologies similar challenges persist across the region over time. The exclusion at the foundation of the states placed "national identity" at the heart of postcommunist politics and offers considerable insights for comparison of the causes, effects and challenges of identity politics in wider Europe.
\end{abstract}

It is widely agreed that the dynamics of state-society relations across the wider European region are up for revalidation. In the EU, and particularly in Central Eastern European (CEE) Member States the trajectory of political development has been uneven and the record of democratic consolidation patchy. While the democratic idea remains close to non-negotiable across Europe and the world more broadly (Shapiro 2003, 1; Schimmelfennig, Engert, and Knobel 2006), the situation is peculiar in Central Eastern Europe as ordinary people there perceive it to be rather different from what many anticipated would come about after the end of non-democratic communist regimes (Rose, Mishler, and Haerpfer 1998). Over the three decades of EU accession, integration, and membership, East European citizens have generally learnt to appreciate democracy over the regimes previously in place: disengagement from meddling in citizens' lives. Constrained by both, commitments to legal corpus as EU Member States and pressures of global political economy, Eastern Europe's democratic regimes have delivered well on this hope of their citizens. But CEE states' limited ability to provide service and support to their citizens and offer opportunities for improving their own lives continues to pose a challenge for the ongoing consolidation of the relationship between the state and society in postcommunist Member States. This sets the CEE region apart from other countries

\footnotetext{
${ }^{*}$ Dr Timofey Agarin, Senior Lecturer in Politics, Centre for the Study of Ethnic Conflict, School of History, Anthropology, Philosophy and Politics, Queen's University Belfast, 25 University Square, Belfast, BT7 1NN, Northern Ireland, UK. Email: t.agarin@qub.ac.uk
} 
in the EU. Whether it is states that ought to serve citizens, or it is citizens that should be satisfied that their states assume the role of "night watchman" is still up for debate in the region that emerged from behind the Iron Curtain to join the EU fifteen years later. Thus, the starting contention of this article - and the symposium - is that the EU accession marked the end of institutional transition and restructuring; however, the question of who and how the institutions of the state ought to serve, has not been settled then and it is far from agreed upon to this day.

In the nearly three decades of (liberal) democratic politics in the region, citizens have primarily experienced the absence of state support when needed. They have accepted the prohibition of discrimination, rather than the promotion of citizens' individual and group rights, and the "lean state" rather than a responsive partner of society (Bohle and Greskovits 2012). It is thus no surprise that postcommunist citizens see the essence of a liberal democracy in state non-interference in private lives (Tismaneanu 2002). Licia Cianetti refers to popular disaffection with democracy as an effect of "stunned interactions between democratic institutions and the populations these serve" (Cianetti 2018). As such, today more than before the EU accession, citizens of postcommunist Member States appreciate contemporary political regimes not for what they do, but for what they do not do (See also, Mishler and Rose 1999).

This situation is not unique to Central Eastern Europe: Re-negotiations of the state-society compact are ongoing across the EU. Whereas over the past three decades references to a gamut of identities have played a central role in politics across the postcommunist region, the increased allusion to nativist tropes, populist rhetoric and radical right ideology in the "old" Member States makes the CEE region a useful context to reflect on such Europe-wide dynamics (Pirro 2015; Minkenberg 2013). Yet, setting postcommunist countries in opposition to the rest of the "Europe" obscures diversity within and between the "new" Member States (Agarin and Regelmann 2011). It also obfuscates similarity in the institutional appeal of nation-bound ideologies across the whole of the EU, which, despite the apparently different expressions in East and West, allows political elites to peddle identity-focussed rhetoric (Agarin and Cordell 2016). In both regions, the phenomena of a surge in nativism and a rise of populism often co-exist, but their root causes and consequences are distinct: Populism is both an ideology and a rhetorical strategy, it has long been a tool for elected or aspiring political elites to lure electorates into the aspiration of society where the "likes are rules by the likes" (Wimmer 2008), both in East and West. At the same time, nativism appeals to 
citizens' and elites' preferences to maintain the coherence of ethnonational political community and avert institutional change that challenges the (perceived) homogeneity of and within the national citizenry. This process has been part of postcommunist transition, since all postcommunist nation-states were established to challenge the shortcomings of the past regime and to share a similar foundational dynamic of accounting only for the interests of the local and/or dominant "people". Across the Eastern European region, we observe that the states originally designed as bulwarks of (ethno-) national sovereignty have over decades normalised the domination of groups that fit easily into the narrative of a homogenous national community and gradually shifted categories of "others" to exclude anyone with "spurious" links to the ethno-national community.

Our symposium looks at the CEE region as an ideal lab to study these Europe-wide phenomena that facilitate, encourage, and sponsor politicisation of identities (See, Hanley and Sikk 2016). We focus on causes for successful mobilisation of identity in politics and the identities' sustained salience across the CEE over the past decades. Given the limited capacity of the EU to enforce and oversee the rule of law across the entire CEE region, identity politics challenge the view that (market) liberalisation and European integration are the vehicles of democratisation and bring improvement to state-society relations by default. In this context, identity politics are a form of societal cohesion advanced by state institutions and political elites that commit to serve one (national majority) constituency above all others. In ensuring that the outcomes of political process are preferentially distributed to that community alone, they undermine perceptions of equality in representation and participation of those groups who perceive themselves as excluded from accessing the political, economic, social and cultural opportunities of liberal democracies. And, since questioning the value of pluralism underpinning liberal democratic politics folds into preference for politics focussing on identity, increasing numbers of CEE citizens doubt that their states serve them well. Additionally, they feel that EU membership has not brought the (vaguely defined, yet expected) benefits they have anticipated two decades earlier, while many perceive that the membership in this supra-national, quasi-state organisation is eroding the national fabric of societies.

This symposium focusses on the ongoing renegotiation of the state-society compact in the light of the continuous salience of "identity" across the postcommunist Member States Poland, the Czech Republic, Slovakia, Hungary, Romania, and Bulgaria. Societies in all these states share three key elements: the consolidation of an anti-pluralist political establishment 
dominated by parties, personalities, and networks that command control over formally liberal democratic politics; scepticism of the role EU's equality and non-discrimination legislation has been playing to ensure lasting societal stability and peace across the wider Europe; suspicion of minorities, particularly the racialised "others" (such as Russians in the Baltic and Roma everywhere) and of groups perceived to challenge the received gender "norms". The following articles examine the dynamic role references to the homogenised identity of the "people" continue to play in the politics of CEE nation-state-bound societies.

\section{Eastern Europe's People’s Democracies}

Observers suggest that despite the fundamental redesign of Eastern Europe's political institutions and policies during the EU accession phase, majoritarian politics and plebiscitary politicking have been rather persistent both before and after joining the EU (Stroschein 2019; Enyedi and Linek 2008; Pirro 2014). Most notably, the political project of nation-statebuilding constricted the debate on issues of identity and belonging, affecting which members of society are considered as part of the "politically relevant communities". Over time, the voice of the numeric majority emphasised that the aspiration to join the EU was a "national" priority, consolidating this "ethnonational" approach that entails the political representation of some, but explicitly not of all residents of the state. The unanimous support for and virtual absence of an opposition to nation-state-building throughout the 1990s have allowed political entrepreneurs to successfully capitalise upon public ascent to facilitate speedy EU accession. As the aspiration of EU membership was widely shared across all states and segments of Eastern European societies, political contestation of the accession process was a non-issue; this in itself has justified the political elites' technocratic approach to political decisionmaking and made it acceptable.

Arguably, the notion that there is "no alternative to joining the EU" has consolidated the socalled "vacuum effect": Eastern European societies are acknowledged to have equivocally supported the transition from communism to shed institutions of non-democratic political regimes. While (almost) every citizen was open to their country joining the $\mathrm{EU}$, few had a clear sense of what the EU membership entailed for their country's domestic political process or their personal engagement with democratic politics. There was far less consensus about the remit of postcommunist institutions, such as the rule of law, checks and balances on institutions, rights for minorities, and active participation of all people affected by the 
political process; and, almost no debate on the content of postcommunist democracy. During the postcommunist phase, the central concern in the accession states was the survival of state founding nations, forming the political objective to join the EU. It was anticipated that membership in the EU would bring positive trade-offs for national ethnopolitics, assuage regional security concerns and offset the constraints of global political economy (Petsinis 2019).

The transition of the region away from socialism towards market-oriented liberal democracies was central for the region's "return to Europe" (Mikkel and Pridham 2004) and states willingly undertook "self-orientalisation" in order to "once again" become European (Krastev 2002; Bunce 2005; Bideleux 2015). This focus on the transition from communism has empowered political elites who, "by capturing state institutions and resources and employing them for electoral gain, [...] weaken[ed] democratic institutions" (Dimitrova 2018, 262). Examining the shortfall in the EU's democratic conditionality, some point to the "Leninist" legacies of the past, specifically to the aversion of debate about alternatives and preference for "getting on with the homework" (Jowitt 1993; Agarin 2013). Others, acknowledge that the inevitability of EU membership has discouraged engagement with issues of politics in societies that have not had much experience of democratic deliberation under socialism (Horvat and Stiks 2015; Anduiza, Guinjoan, and Rico 2019), while privileging politics focused on affirming and consolidating the newly acquired identities (Donskis 1999; Laitin 2002; Huszka 2014).

The individualising thrust of EU's liberal politics during the accession phase had allowed ample space for political leaders to thrive on concerns over national identity and state sovereignty, consolidating the earlier pre-accession embryonic national identity-politics. As the contributions to this symposium demonstrate, for many postcommunist citizens, EU membership failed to deliver on original expectations, such as economic stability, the primacy of domestic over external, i.e. European decision-making, and to dispel concerns over national security. This happened despite the concerted efforts of competing fractions among the political elites who appeased electorates with a penchant for strong leadership to exploit consensus over the EU accession (McGann and Kitschelt 2005). In turn, this fused political and electoral contestation with concerns over form, rather than content of democratic politics.

By 2019, most postcommunist states have been holding free and fair elections on a regular basis, satisfying the Schumpeterian ideal of competitive democracy (Schumpeter 1947: 269; 
Huntington 1991). There is no doubt that all postcommunist Member States are electoral democracies, which allow their people to express consent or to contest decisions of their representatives, while enjoying broad political and civil rights, freedom of speech and association (Dahl 1972). Unlike in the past, when political competition and citizens' enjoyment of individual rights were either circumscribed, or non-existent, the mere opportunity for citizens to input political process is often taken as evidence for successful postcommunist democratisation across the region.

The experience of the accession to the EU, the establishment of market economy and liberal democratic governance all offer a comparable institutional background to understand the ongoing renegotiations of state-society relationship across the continent. But whereas formal democratic institutions are similar across the EU, the CEE citizens remarkably often choose to avoid interacting with these institutions in their states unless they need to. The absence of public participation in political decision-making has been central to criticism of the formally democratic postcommunist democracies (Howard 2003; Agarin 2016). In these regimes, structural inequalities and uneven distribution of the state's socioeconomic assets, particularly between majorities and minorities (Rueschemeyer, Rueschemeyer, and Wittrock 1998; Morlino and Quaranta 2016), have, over time, consolidated the limited advancement of rights and protections for minority groups (Lijphart 1997) and undermined public debates on the ultimate purpose of democratic governing, government, and governance (Dryzek 2000; Hurrelmann 2015).

In many postcommunist states elites are not committed to stepping aside (Hale 2014; Shaw and Wiener 2000), nor do many postcommunist elites resolve differences on policy preferences in a consensual manner (Bochsler and Kriesi 2013). Unsurprisingly, political leadership across the region has been said to poorly reflect the interests of the publics, as during their term in office, the elites oftentimes predatorily continue to extract benefits for their own networks, rather than serving their broadly defined constituencies (Kitschelt and Wilkinson 2007).

No doubt, Eastern Europe's Member States have all the hardware of liberal democracies in place (Rose, Mishler, and Haerpfer 1998), yet it remains uncertain whether the version of its software pivoted on "Washington Consensus" runs to the satisfaction of postcommunist citizens. As Geoffrey Pridham cautioned in 2002, "the EU strengthening executive and bureaucratic power without active popular engagement $[\ldots]$ creates a potential for widening the gap between political elites and masses, already a problem in many post-communist 
democracies; and, hence, for creating disillusionment when democratic attitudes have not fully taken root" $(2002,954)$. Somewhat more recently, Dorothee Bohle and Bela Greskovits have argued that postcommunist democracies have been marred by low quality (2007), later adding that these had but a shell of liberal democratic institutions and procedures, poorly understood and only conditionally accepted by citizens (2012).

Postcommunist transitions started with an aspiration to bring democracy to "the people", but political transformations remained focussed on the nation-state. Who owned the state and who was to benefit from the "national optic" on societies varied considerably across the CEE region and over time, depending on historical legacies, the respective socio-economic situation, and geo-political factors. Yet, the everyday perception of the "people" translated into the political jargon via the familiar, "national" trope of "a historically constituted, stable community of people, formed on the basis of a common language, territory, economic life, and psychological make-up manifested in a common culture" (Stalin 1936 [1913]). This marked polities as confounding the nation, establishing non-negotiable narratives that permeated the public debate, shaped preferences for economic and public policies, and geopolitical orientations. Since 2004, all countries in the region have, to some extent, engaged in dismantling the acceptance of societal pluralism underpinning liberal democratic politics (Bustikova and Guasti 2017; Hanley and Vachudova 2018), fostered public disaffection with the political process by capitalising on communist socialisation (Howard 2003; Ekman, Gherghina, and Podolian 2016), evacuating the "political" out of politics (Dawson 2016; Cianetti, Dawson, and Hanley 2018), or failing to provide positive experiences of participation in decision-making (Kolstø and Melberg 2002).

It is open to debate whether such government without consensus merely got worse over the past decade or did not evolve in the first place (Harris 2019; Braghiroli and Petsinis 2019). Some suggest that the parties' failure to gauge people's opinions (Mair 2006), institutional complacency and backsliding (Greskovits 2015), and technocratic abuse of power (Cianetti 2018; Buštíková and Guasti 2018) have marked politics in the Eastern Europe throughout the period of transition. Over the past decade, dominant groups in nation-states have rediscovered the powerful role that identity can play in mobilising the "people" against "minorities", to scale back the "benefits" afforded to these at the expense of the constitutionally enshrined rights of the ethno-nation that owns the state. In doing so, most postcommunist Member States, not only Poland and Hungary, have reneged on some of their commitments made under the Copenhagen Criteria: These criteria clearly established the requirements for liberal, 
non-majoritarian democracies, which limits significantly the type of policies, politics, and, indeed, politicking that the members of the Council of Europe and of the EU ought to pursue. However, since the accession, political process gradually returned to the original postcommunist people's centred politicking advocating both the majoritarian and plebiscitary decision-making. Taking this mandate of the "people" to protect the majorities' interests, states became stand-ins for the "nation", normalising the "national optic" on domestic politics and eroding deeper commitment to the equality of all citizens of the EU.

The articles in this symposium recount a story of unchanged political preferences across the CEE region, not because of the fading legitimacy of the EU, but rather due to the continuous and growing appeal of a nation-state-majority compact. While the aspiration to join the EU was shared across postcommunist populations, in practice, little knowledge about the concrete effects of membership allowed publics to invest whatever their elites promised it would not be. Isolating the "people" from their past experiences justified bowing down to both the acquis and political conditionality if only to secure national sovereignty in a Europe of "free nations". Primarily, this included the view that the EU would not interfere in national politics, protect Member States' nations from the economic hardship and countenance geopolitical volatility - all of the aspirations at the heart of the Eastern European national movements' emancipatory appeal of the late 1980s. Following accession, however, a somewhat more cynical attitude towards membership made itself present: "European" was no longer self-evidently perceived of as something desirable, as the sceptics have increasingly become intent on portraying the "liberal European agenda" as antithetical to, or even a threat to the peoples', "national values". In sum, the payoff of membership has now become negligible for accepting the encroachments on the decision-making capacity of one's "own" nation-state.

\section{Postcommunist State-Society Compact}

Over the nearly three decades, postcommunist political elites have been smiting alliances with variant ideologies with - in part contradictory - economic, political, cultural and religious connotations, effortlessly coming and leaving the political office without major shifts in polities' overall EU-oriented rhetoric. Yet, critical references to the Soviet/communist "Other" have been persistently marking only a "thin ideological commitment" to consensus-based decision-making, whilst invoking the "interest of the people" (Stanley 2008). Political elites shoring up their support base and mobilising identity- 
focussed constituencies have all been nested in the narrative of the state serving the ethnonation, and, as such, demanding compliance, not challenges from the "people". Rather than a case of "sharp political conflict" between the "people" and the elites observed elsewhere in the EU (Plattner and Diamond 2007, 5), the spread of the so-called populist political forces in the East of Europe marks continuity rather than change in the state-society, more specifically in the nation-state - majority compact established at the beginning of transition.

At the beginning of transition, the long-term "national priorities" credibly justified that some - in the short term impalpable - decisions were made in the interest of "the people" and commanded popular deference to choices, however misguided, of people's representatives. Earlier exclusionary practices targeted those not part of the majority of the population, whether in regard to ethnicity, language, tradition, civilizational or party identity, but following the EU accession the challenges to the established status quo come from other quarters. The "people-centred" democracies have since seen a weakening of the democratic process as publics have brought feelings of dejection into the open, polarising public opinions and pitting the "people" against those "running the state" (Buštíková and Guasti 2018; Agarin 2013).

Many established democracies currently experience the decline in public support for the political establishment, but the accompanying decline in the quality of democratic institutions and of a state's ability to cater to the needs of its society, that are of particular worry to observers. This rise of "people versus elites" ideologies has been acknowledged to affect most, if not all European states, and scholars studying populism often start by recognising the increasing dis-identification of publics from their elected political representatives (March and Mudde 2005). This shift is expressed in the attitudinal change from dejection to rejection of democratically elected political leaders, of consensus based political decision-making and, even in the formally established democracies, of guarantees for citizen equality.

The dismal state of popular engagement with the democratic process as well as a lack of feedback mechanisms between political elites and publics on issues of electoral salience are made responsible for the erosion of trust in representatives, institutions, and regimes as a whole. The "downhill trend" in these is often contrasted with more intensive interactions that citizens (are believed to have) had with the governing elites, governments and processes of governance in the past. One could speak about the outright "populist explosion", both as a political phenomenon and as an object of study (Judis 2016). While some state that populism is on a "global rise" (Rooduijn and Pauwels 2011), going as far as asking "is everyone a 
populist now?" (Müller 2016, 7), others remain more sceptical about the analytic weight of such distinctions (Kessel 2015), or wonder whether we are dealing with an epiphenomenon at all (Pappas 2016; March 2017). Focussing on populism as an antidote to democracy, as many do, suggests a zero-sum game between the two, a view that has been thoroughly discredited long before the transition from communism began (Canovan 1983). Criticism of obsession with the "rise of populism" mount from the left and right, indicating that the term obstructs more than it is able to explain (Cannon 2018). If, as Margaret Canovan claims, "the sources of populism [...] are to be found in the tensions at the heart of democracy" (Canovan 1999, 2), we ought to identify liberal democracy as the context most prone to the rise of "people versus elites" ideological alternatives.

The answer to the question, why populists' gain of political ground in the (still so-called) "new" Member States causes particular dismay in observers, points to the heart of the problem of ill-defined state-society relations in the postcommunist area (Bustikova and Kitschelt 2009; Rupnik 2007; Minkenberg 2002). For one, it is because "people centred" politics have a much longer history in the region. The dynamic relationship between liberal democratic institutions of postcommunist Member States, political elites operating these institutions, and the publics that confirm the appropriateness of the political process with their expectations at regular intervals via the ballot box, are highly comparable with those in the wider Europe and beyond (Sandel 2018; Ayyangar 2017; Bugaric 2008; Buštíková and Guasti 2018). And while the people-centrism in domestic politics constricts and constrains the "real existing" diversity to be represented in the liberal democratic political process, states are uncritically accepted to serve the (purposefully vaguely-defined) "majority" that pivots on experiences of ethno-cultural, language, religious, civilisational, territorial and historical homogeneity. In practice this allows postcommunist citizens to view their elected elites as "natives" dancing to the tune of the European (and other situationally significant) "aliens" (See, Mudde 2009 chapter 1).

The compact between the "people's majority" and the political elites speaking on their behalf justified the technocratic approach to solving challenges during the EU accession. And, this broad societal consensus about the desirability of the EU membership prevented Eastern European societies from engaging with the compromise-based, rather than majoritarian forms of decision-making in publics and among their elected representatives. Along the way, the instruments available to the nation-state to exercise cohesion over its entire citizenry foreclosed the debates about alternatives to the overall direction of political, economic and 
social transitions to unfold once the EU membership was achieved. The emphasis on majoritarian and plebiscitary democratic decision-making facilitated acceptance of painful reforms during the critical period of transition; it has also de-legitimised (nearly all) legacies of the communist past as being made in the interest of the ideology, party, or bureaucracy, not in the name of the "people" (Cordell 2013; Karolewski 2016). Yet, the nature of the EU accession and membership did little to reform populations' acquiescence to decisions made by political elites representing them as one "people", not as citizens with diverging interests. Regular executive and legislative elections continue to keep politicians and politics in check, the (unelected) representatives in the judiciary continue to balance legislators and presidents keen to roll back democracy, but sufficient numbers of the electorate are yet to show enthusiasm for a challenge to the experts making decisions for the people (Barnes and Simon 1998; Orenstein 2009).

The EU's Eastern enlargement has been widely perceived not only to promise a departure from non-democratic political regimes for good; in co-opting the view that "Europeanisation equals democratisation", it increased the stakes for both the elites and the people in the accession states to cooperate in the short term to benefit from governance closer to "the people" in the long run (Agarin and Yilmaz 2016; Noutcheva 2016; Keil 2013; Schwellnus 2006). As such, the EU accession only facilitated the consolidation of "the people" around the putatively homogeneous "nation". National identity retained it prominence in Eastern European politics because the EU accession process foregrounded the democratic consolidation of states in their existing national form, assuming (mistakenly) that all residents - majorities alongside other groups originally marginalised from political decision-making would have their lot improved once liberal democracy, that is, non-intrusive political regime settles in. The hard-to-stomach outcomes of the EU membership, such as those of commitment to joint decision-making, economic cooperation, and obligations to prevent discrimination, paved the way for more restrictive views on who owns the state, who is entitled to run it and who is to profit from its current configuration (Agarin and Cordell 2016).

A technical view of the EU accession process, therefore, has compromised the underpinnings of postcommunist states' European integration at large, and questioned the EU's objective of forging a functioning political community of interdependent states, not sovereign national communities (Scicluna and Auer 2019; Kochenov, Ridder, and Eline 2011). In the past, the EU's promotion of citizen equality has gone beyond a shared view of financial discipline and 
economic cooperation, ensuring independence of political and judicial institutions. This has also allowed the EU to tame mutual distrust between Member States and their peoples, to balance the centrifugal nationalisms across the continent and to forge a semblance of European polity (Plattner and Diamond 2007; Sedelmeier 2017). But, and once EU membership was guaranteed, the political institutions that were shoring up national identities had already formed the experiential background for "political entrepreneurs" to pursue politicking around exclusive societal categories. This hailed the ascent of concerns over national identity into politics as soon as political, economic and cultural exchanges within the EU have made clear that the identity of nation, people, and their elites did not map well onto one another. Identity politics of "the people" were reinvigorated becoming identity politics of "the (ethno-)nation".

The single-issue politics that defined the accession phase have returned under the guise of identity politics in the post-accession phase, allowing voters to easily ascertain their preferences in an uncertain political landscape. Issues that once were recipes for political success - fighting corruption, guaranteeing welfare, addressing environmental concerns, catering the regional or ethnic cleavages, and tackling immigration - eased the arrival of parties mobilising around the interests hard to place on the "traditional" ideological spectrum between left and right. As it turned out, nation-state building successfully appeased the "demos", promoting ethnocentric views and shifting the overall political dynamics from concerns over issues to politicising markers of identity.

The central role played by identity in Eastern European politics has laid bare the tension at the heart of transition from communism to democracy. Where little experience of consensusbased politics was to be found, politics of identity offered institutional opportunities to vent public anger, challenge "outward looking" political agendas and leadership. At the same time, the prevalence of institutions serving discrete interests of "national communities" encouraged political entrepreneurs to talk-up the social salience and relevance of identity in politics. The fact that many postcommunist states were reconstructed as polities serving designated ethnic majority groups reflected closely on the nation-focussed political ideologies in a volatile geopolitical environment (Agarin 2017). The notion of the national community under threat from global political, economic, and cultural forces sat at the heart of late socialist popular movements for emancipation from external, usually Russian, dominance. Today, similar narratives barrage "Europe" as the last vestige of oppression. 


\section{The Salience of Identity Politics}

The demise of socialism has quickly become embodied by the vision of an "end of history": The initial diagnosis that publics' ideological commitments to socialism were low, while affinity for the Western style democracy high, seemed accurate enough due to the fact that postcommunist citizens defected to market economy and liberal democracy en mass.

However, acquis conditionality over the "short decade of accession" only entrenched laws and institutions to guarantee CEE states the ability to assume rights and duties as Member States, with little attention paid to benchmarking norms of liberal and pluralist, democratic politics. And too little attention was given to reforming other, more salient aspects of societal acquiescence with the political process: For many postcommunist citizens, the falling away of socialism meant just that, the end of external patronage and the ability to take politics into one's own hands.

The disengagement of publics from politics has been a persistent feature across Central Eastern Europe since early 1990s. Despite turning up in (considerably) higher numbers to cast ballots on landmark decisions, such as on the composition of the first postcommunist governments, to join the EU, or more recently to oppose the EU's refugee quotas, the populace has mainly been approving, rather than rejecting governments' proposals throughout. However, the recent protests across the region bare continuous witness that the debate between those favouring elite- or citizen-centred politics is still outstanding. The "people" taking to the streets of Bucharest and Budapest, Warszawa and Bratislava all marked the return of extra-parliamentary debates on politics out of sync with public expectations. These send mixed messages about citizens' preferred changes and come from pro- and anti-government groups, some coming out in favour of greater liberalisation and more technocratic politics, others for the protection of the "national" from global political, economic and cultural challenges. The nature of public disaffection thus expressed indicates that politics responding to citizens' interests are currently being replaced by politics concerned with identity of the "people" across the wider region.

In response, the elites representing the increasingly polarised electorates have taken on to redefine what it means to belong to, identify with and gain from the resources managed by “their" states (Kopecký and Mudde 2000). As earlier EU enthusiasm is being replaced by criticisms of Europe's contribution to democratisation (Lendvai 2004; Vachudova and Hooghe 2009), economic liberalisation (Berman 2003; Đurašković 2016) and cultural 
changes (Urbinati 2014), question whether Europeanization and democratization possibly pull Member States in different directions have become louder throughout Europe (Bideleux 2001; Kochenov and De Ridder 2011; Ágh 2018).

The limited past involvement of the public in the process of governing has been made responsible for the EU's democratic deficit (Rohrschneider 2002; Kelemen and Blauberger 2017; Blatter, Schmid, and Blättler 2017), and it explains why citizens have been seeking to "take back control" after the European crises. Yet, little, if any, debate takes place about who the "people" are, or what is the shared aspiration by these putative "people". However, the new style of politics makes wide use of the rhetoric of responsibility and responsiveness to the electorate, promising better politicking by and outcomes for the "people". Yet, referencing the "people" is "tailor-made for catch-all politics, and analysis of its use can easily turn into a study in the pathology of modern democratic politics, or how to talk nonsense to the greatest political effect" (Canovan 1984, 322).

The Eastern European Member States offer a unique set of cases in this regard: European crises not only polarised their domestic electorates, but equally marked the region as comparative laggard of political, economic, and social transitions. Because citizens of postcommunist states envisaged that their countries' membership in the EU would improve their personal, social, and economic wellbeing, European crises have dented the optimism of the infallibility of the EU's model of governance. While the benefits of the regional as geopolitical alignment with the EU are still cherished by most states in the region, their many citizens are increasingly reluctant to accept other parts of the bargain. Stretching Claus Offe's (1991) analogy comparing postcommunist transitions to building a ship at high sea to consider the challenges of consolidating the market economy, democracy and the nationstate simultaneously, we can see that as soon as the storm gathered on the horizon, some of the original aspirations, particularly pluralist democracy, went overboard.

Some observers underline the view that democracy failed to crystalize at least in parts of Central Eastern Europe (as yet); this is an unhelpful shortcut in reasoning showcasing an "unacknowledged bias equating democracy with its liberal variant" (Cannon 2018). We ought to acknowledge that several views on what democracy is have coexisted peacefully over half a century of communism in the Eastern European societies, but only one of these versions has persisted during postcommunist transition and became the norm during the EU accession phase. Assorted left and right populist challengers to contemporary models of governance point out that East European citizens continue to vest "democracy" with a rather different 
meaning than the one favoured by the EU (Rueschemeyer 2015; Ágh 2016). Thus, labelling political movements that challenge the political status quo regardless of their ideological positions or programmatic proposals, does not only stifle the debate about any potential for reform, but ought to be welcome as democratic contestation of meaning, content and form of governance. Absent in the past, alternative visions of democracy seem to emerge across the region seeking to engage wider segments of society in political debate and appease the "people", much like other postcommunist political elites have done so over the three decades of transition.

In part, the effects of nation-state building across the region have caught up on domestic politics following the EU accession when external leverage could no longer be applied to correct the "nationalising" aspirations of the states (Brubaker 1996). In some postcommunist Member States, politics by and for the national majority brought societies divided over ideological principles together into one political community. In all cases, however, the putative majorities were united in their commitment to the democratically expressed (read: plebiscitary) will of the "people" delivered upon by the elite-enforced decision-making. Particularly in the countries that originally grappled to defend the "national sovereignty" from external and domestic ethnic challengers, all types of non-dominant groups found themselves objects of securitisation, and ultimately marginalisation, by the formally liberal democratic institutions thirty years after the start of transition from communism.

Similar strategies are widely deployed by political entrepreneurs often boxed together into the "populist" camp. But the reason for the regional drift towards populist politics has been similar in so far as most of the Eastern European states have either been established as or have entrenched the commitment to national identity over the decades. A crucial feature of these references to the nation is that they have normalised the view of a putative national homogeneity vis-à-vis equally homogenous "others" across the region. These ever-changing "others" are perceived to challenge, and more often threaten security and, ultimately, stability of, one's own group's hold on power, regardless how minimal it is. This in turn showcases the persistence of identity-based mobilization in diverse postcommunist societies that are served by polities that have been exclusionary by design from the start. Against this background, our symposium looks at EU integration as an opportunity missed to demobilise (national) identity-focussed politicking, politics and policies favouring majorities across postcommunist CEE societies. The following contributions particularly focus on how concerns over the coherence of political and national communities across the region have 
remained a constant feature of national politics and how the majority's identity retained salience in such politics.

\section{Contributions of the Symposium}

Our articles address developments across the region over a considerable period of time. Contextualising the concerns of each country at the time of accession to the EU that have remained salient, the articles revisit three aspects of politics in the region since accession: Public disengagement from discussions of political ideology and about the direction of political, economic, social-cultural change in their societies; the continuous tutelage by political elites over public perception of programmatic issues, shaping and manipulating opinions of the largely dejected citizenry; the obstinate resonance of nation-focussed ideologies in the absence of other ideological commitments to underpin the "political community" across the entire spectrum of postcommunist Member States.

The articles of this symposium rely upon and contribute to three discrete debates in scholarship on Eastern European politics and societies: First, we engage in discussions on the current response of CEE citizens to the consolidation of political regimes that many believe do not serve their interests. Though some of the cases broach the theme of "populist revolution", this collection makes clear that the tentative "democratic malaise" of populism has been a feature of the region for a long while. The articles do suggest that the "weakest link" of the region's democracy are its publics, the "demos". The limited consensus among the citizens about the identity of the "demos" has been repeatedly mobilised by competing forces for the exploit of their own version of "kratos", the "power to" that is particularly attracted to majoritarian politics. Concerns over identity of the public with their state, their nation, and their belonging to European civilisation have been systematically manipulated to consolidate the exclusionary logic of nation-state building.

Second, the contributions assess the impact of the EU's technocratic implementation of (liberal) democracy with market economy as the "only game in town". All articles take stock of discussions on the impact EU membership had on the formal quality of democracy across the region; in all countries this pushed the debates about the nature and the purpose of governance into the background. This has undermined the original commitment of postcommunist publics to participatory democracy and allowed the consolidation of nationstate institutions serving predominantly the putatively homogenous "collectivities of fate" 
(Dahrendorf 2003). The political entrepreneurs underlined that departure from communism equals functioning market economy as well as liberal democracy for the designated majorities. Opinions that did not receive institutional support were side-lined. In so doing, the entire set of postcommunist Member States is marked up by distinct - parallel - spaces for politicking by political entrepreneurs engaged in tutelage of publics increasingly questioning elite commitment to people's democracy (Petsinis 2019).

Third, our articles signal that the EU's inability to sanction the equivalence established between the identity of a person, a people, citizenry, and a nation in the postcommunist region has kept identity politics on its steady course over thirty years. Estonia, Latvia, Lithuania, Poland, the Czech Republic, Slovakia, Hungary, Slovenia, Romania, Bulgaria and Croatia have joined the EU in subsequent rounds of enlargement, 2004, 2007 and 2013. However, despite the different timing and conditions of their inclusion into the EU, these countries' "choice of Europe" has been justified by economic benefits trickling down, political clout and national sovereignty afforded to all EU's states qua membership. The articles assert that as a result of EU membership much has changed in the manner of politicking across these wide geographic areas, yet the issue of nation-centred sovereignty that originally drove the transition from communism continues to focus the region's contemporary politics on the ethnic identity of the majority.

However, the contributions to this symposium eschew the engagement with discussions on what legitimised such focal identities across the region in the first place (See, Agarin and Regelmann 2011). Such engagement would be specific to communities operating such categories, for example, state majorities will clearly have a different view from members of minorities. At the same time, the compactly settling minorities, e.g. Hungarians in Romania or Slovakia, would have their own unique views on who "owns" the territory they inhabit and consequently, who is the majority. Categories of "majority" would also inevitably change over time, e.g. the view on what makes a "real Pole" in Poland proper has undergone considerable change since Prawo i Sprawiedliwość (Law and Justice) ascended to power; domestic dynamics in Hungary also had a knock-on effect on the political use of identity claims by Magyars in the neighbouring states, Romania above all. Thus, each article tackles the question of who the majority is from their individual comparative angle, teasing out differences in cases, but above all similarities across the region. 
Daniel Bochsler and Andreas Juon offer a comparative analysis of the quality of democratic institutions across the postcommunist region (Bochsler and Juon 2019). The authors conclude that though institutions of democracy might be robust across much of the region, a democracy's quality varies depending on the likelihood of political elites turning to the tools of authoritarian government. The limited capacity of the EU to benchmark democracy in its Member States and the weakening of the incentives offered by European integration after the global financial crisis form the background for public disaffection with democracy as such. The article explains that not in all cases where the populists have entered governments can one observe democratic de-consolidation; however, after the logic of past accession and potential membership has encouraged elites to appeal to the "power of people" in order to remain in the driving seat.

Kiril Kolev argues that the recent rise in identity politics in Bulgaria and Romania is due to a weak commitment to pluralism and the limited consolidation of publics around the idea of democratic politics (Kolev 2019). The article traces the evolution of societal attitudes towards pluralism before and after the EU accession process in Bulgaria and Romania. Kolev suggests that externally imposed policies sponsoring cultural pluralism and the tolerance of diversity in political opinion were not reciprocated by the populations. The analysis links the relatively more pronounced lack of subcultural pluralism in Bulgaria to a more vigorous anti-EU backlash during the current period, while deference to political elites' decisions has been reflected in the widespread anti-elite sentiment in Romania. In neither cases, however, does the paper find public acceptance of pluralism and commitment to equality critically important for a robustly democratic political process devoid of references to national identity.

Petra Guasti and Lenka Bustikova explore the dynamics and the outcomes of a backlash against the LGBT community in the Czech Republic and Slovakia (Guasti and Bustikova 2019). The authors start by distinguishing the "old" from "new" minority groups, indicating that while ethnic minorities tend to field particularistic demands, LGBT rights are universal and hence should, in theory, facilitate coalition building and advocate policies of accommodation. The evidence from the Czech Republic and Slovakia shows that paradoxically the translation of universal claims from the LGBT discourse into policymaking faces the greatest resistance, blocking progress in respective legislations for extended periods. This, as the article suggests, reflects the overall dynamics on the region-wide opposition to ideas of equality concerning groups that challenge the social agendas of politics grappling with the visible erosion of a uniform identity of a national society. 
Robert Sata and Ireneusz Pawel Karolewski focus on the cases of Hungary and Poland, the two states where the erosion of democratic institutions has gone in hand with the surge of identity politics (Sata and Karolewski 2019). In both countries, the weakness of national democratic institutions was used by the opportunistic leadership, who was able to extract political capital out of public disappointment with the stalling economy. The authors describe how the use of patronage and power-hoarding by the ruling elites has facilitated societal mobilisation around exclusionary identities that shifted democracy towards, what they term, Caesarean politics. The concentration of decision-making power in the hands of individual leaders and its management by cartels of elites has made access to the political networks of PiS and Fidesz an essential element of democratic stasis in both Poland and Hungary. Ruling parties, therefore, have been the main generators of politics focused on identities and tilted a plebiscitary view of political participation in favour of the entrenched representatives of the "people".

Our symposium suggests to focus on the causes of nativism and the rise of populism precisely because both feed-off the same relevance of national identity in politics. The challenge of centring politics on identity is not about the type of government, or the form of governance, but about the institutionally cultivated sense of sameness of the people with their political representatives. This perception of sameness is to justify whatever decisions the elites make, overriding dissenting opinions in the name of the narrowly defined "people" to exercise their majority's mandate. Mobilising concerns over identity to bring about the consent of the affected about the yet to be disclosed benefits is the bread-and-butter of dedemocratisers and populists alike. As can be vividly observed in Greece, the UK, France or Finland (Nordensvard and Ketola 2014; Kovras and Loizides 2014; Lees 2018; Pirro and Van Kessel 2017; Usherwood 2019), questioning institutional checks and balances on the majoritarian decision-making in the name of the "people" is not limited to the postcommunist region.

To illustrate the similarity between "East" and "West", the articles of this symposium put the state-society relations at the centre of their analysis. All of them suggest that rather than galvanised by the notions of pluralism and liberal democracy, postcommunist publics coalesced around the notion of exclusion, upheld by the institutions of the nation-state and by the national political elites. The form and speed of accession to the EU, rather than its content, paved the way for, rather than challenged the salience of identity in politics across the CEE region. All articles look at how the "national self" has been constructed first in 
deference to, then in opposition to a notional "Europe", but at all times as antagonistic to external regional and domestic "others" who violate the perceived perceptions of national homogeneity of the in-group. This group, usually an ethnic nation, is (thought of as being) both perennial and homogenous, upholding the idea propping up the nation-state majority's claims to state ownership.

The symposium as such speaks of state-society relations, that are still negotiated in the region and of which the outcome is not yet clear. Whereas similar processes are currently taking place across the board of the EU Member States, political regimes in CEE a decade and a half since the EU accession have settled on the overtly idealised image of the "nation" for which states exercise decision-making. In some parts of the region, the initial mass disenfranchisement from citizenship (as was the case in Estonia, Latvia, and Slovenia) added a clearer component of ethnic exclusion. But everywhere, the inclusion of only a part of the citizens into the category of a socially salient and strategically relevant political community is what explains the persistent contestation of the state-society compact and salience of national identity in postcommunist Member States' politics.

\section{Acknowledgements}

I am very grateful to Daniel Bochsler, Petra Guasti, Ireneusz Pawel Karolewski, Lenka Bustikova, and Andrea Pirro for invaluable comments on the earlier drafts of this contribution. Also, thank-you to all authors contributing to this special section, and the participants of ECPR General Conference, Hamburg 2018, as well as of the colloquium of the International Political Studies Association, Research Committee 14 "Politics and Ethnicity", Sarajevo 2019.

\section{References}

Agarin, Timofey, and Ada-Charlotte Regelmann. 2011. 'Status Quo Multiculturalism: The Crux of Minority Policies in Central Eastern Europe's EU Member-States'. Journal of Minority Studies 5 (3): 69-98.

Agarin, Timofey, and Gözde Yilmaz. 2016. 'Talk the Talk, or Walk the Walk? Changing Narratives in Europeanization Research'. Südosteuropa: Journal of Politics and Society 65 (1): 149-69.

Agarin, Timofey, and Karl Cordell. 2016. Minority Rights and Minority Protection in Europe. Rowman \& Littlefield. 
Agarin, Timofey. 2013. 'Resident Aliens? Explaining Minority Disaffection with Democratic Politics in the Baltic States'. Ethnopolitics 12 (4): 331-51. https://doi.org/10.1080/17449057.2012.748247.

Agarin, Timofey. 2013. 'The Dead Weight of the Past? Institutional Change, Policy Dynamics and the Communist Legacy in Minority Protection'. In Institutional Legacies of Communism: Change and Continuities in Minority Protection, edited by Karl Cordell, Timofey Agarin, and Alexander Osipov, 14-30. London: Routledge.

Agarin, Timofey. 2016. 'Citizens' Participation in Post-Communist Europe'. Communist and Post-Communist Studies, 49 (3): 201-6. https://doi.org/10.1016/j.postcomstud.2016.06.008.

Agarin, Timofey. 2017. 'Nation-States into Nationalising States'. Intersections. East European Journal of Society and Politics 3 (4). http://intersections.tk.mta.hu/index.php/intersections/article/view/393.

Ágh, Attila. 2016. 'The Decline of Democracy in East-Central Europe: Hungary as the Worst-Case Scenario'. Problems of Post-Communism 63 (5-6): 277-87.

Ágh, Attila. 2018. 'The Dual Crisis and 'Regionalization'in the Visegrád States: The Identity Politics of East-Central Europe in the New World Order'. In Central and Eastern Europe in the EU, 177-89. Routledge.

Anduiza, Eva, Marc Guinjoan, and Guillem Rico. 2019. 'Populism, Participation, and Political Equality’. European Political Science Review 11 (1): 109-24. https://doi.org/10.1017/S1755773918000243.

Ayyangar, Srikrishna. 2017. The Promise and Perils of Populism: Global Perspectives. Taylor \& Francis.

Barnes, Samuel H., and Janos Simon. 1998. Popular Conceptions of Democracy in Postcommunist Europe. Budapest: Erasmus Foundation.

Berman, Jacqueline. 2003. '(Un) Popular Strangers and Crises (Un) Bounded: Discourses of Sex-Trafficking, the European Political Community and the Panicked State of the Modern State'. European Journal of International Relations 9 (1): 37-86.

Bideleux, Robert. 2001. 'Europeanization and the Limits to Democratization in East-Central Europe'. In Prospects for Democratic Consolidation in East-Central Europe, edited by Geoffrey Pridham and Attila Ágh, 25-53. Manchester University Press.

Bideleux, Robert. 2015. 'The 'Orientalization" and 'de-Orientalization" of East Central Europe and the Balkan Peninsula'. Journal of Contemporary Central and Eastern Europe 23 (1): 9-44.

Blatter, Joachim, Samuel D. Schmid, and Andrea C. Blättler. 2017. 'Democratic Deficits in Europe: The Overlooked Exclusiveness of Nation-States and the Positive Role of the European Union'. JCMS: Journal of Common Market Studies 55 (3): 449-67.

Bochsler, Daniel, and Andreas Juon. 2019. 'Authoritarian Footprints in Central and Eastern Europe'. East European Politics 0 (0): 1-21. https://doi.org/10.1080/21599165.2019.1698420.

Bochsler, Daniel, and Hanspeter Kriesi. 2013. 'Varieties of Democracy'. In Democracy in the Age of Globalization and Mediatization, 69-102. Springer.

Bohle, Dorothee, and Bela Greskovits. 2007. 'Neoliberalism, Embedded Neoliberalism and Neocorporatism: Towards Transnational Capitalism in Central-Eastern Europe'. West European Politics 30 (3): 443-66.

Bohle, Dorothee, and Bela Greskovits. 2012. Capitalist Diversity on Europe's Periphery. Cornell University Press.

Braghiroli, Stefano, and Vassilis Petsinis. 2019. 'Between Party-Systems and IdentityPolitics: The Populist and Radical Right in Estonia and Latvia'. European Politics and Society, 1-19. 
Bugaric, Bojan. 2008. 'Populism, Liberal Democracy, and the Rule of Law in Central and Eastern Europe'. Communist and Post-Communist Studies 41 (2): 191-203.

Bunce, Valerie. 2005. 'The National Idea: Imperial Legacies and Post-Communist Pathways in Eastern Europe'. East European Politics and Societies 19 (3): 406-42.

Bustikova, Lenka, and Herbert Kitschelt. 2009. 'The Radical Right in Post-Communist Europe. Comparative Perspectives on Legacies and Party Competition'. Communist and Post-Communist Studies 42 (4): 459-83.

Bustikova, Lenka, and Petra Guasti. 2017. 'The Illiberal Turn or Swerve in Central Europe?" Politics and Governance 5 (4): 166-76. https://doi.org/10.17645/pag.v5i4.1156.

Buštíková, Lenka, and Petra Guasti. 2018. 'The State as a Firm: Understanding the Autocratic Roots of Technocratic Populism'. East European Politics and Societies, https://doi.org/10.1177/0888325418791723.

Bustikova, Lenka. 2009. 'The Extreme Right in Eastern Europe: EU Accession and the Quality of Governance'. Journal of Contemporary European Studies 17 (2): 223-39.

Cannon, Barry. 2018. 'Must We Talk about Populism? Interrogating Populism's Conceptual Utility in a Context of Crisis'. New Political Science 40 (3): 477-96.

Canovan, Margaret. 1983. 'A Case of Distorted Communication: A Note on Habermas and Arendt'. Political Theory 11 (1): 105-16.

Canovan, Margaret. 1984. "'People", Politicians and Populism 1'. Government and Opposition 19 (3): 312-27.

Canovan, Margaret. 1999. 'Trust the People! Populism and the Two Faces of Democracy'. Political Studies 47 (1): 2-16. https://doi.org/10.1111/1467-9248.00184.

Cianetti, Licia, James Dawson, and Seán Hanley. 2018. 'Rethinking 'Democratic Backsliding” in Central and Eastern Europe - Looking beyond Hungary and Poland'. East European Politics 34 (3): 243-56.

Cianetti, Licia. 2018. 'Consolidated Technocratic and Ethnic Hollowness, but No Backsliding: Reassessing Europeanisation in Estonia and Latvia'. East European Politics 34 (3): 317-36.

Cordell, Karl. 2013. 'The Ideology of Minority Protection during the Post-Communist Transition in Europe'. In Institutional Legacies of Communism, Change and Continuities in Minority Protection, edited by Karl Cordell, Timofey Agarin, and Alexander Osipov, 77-89. Routledge.

Dahl, Robert A. 1972. Polyarchy: Participation and Opposition. New Haven: Yale University Press.

Dahrendorf, Ralf. 2003. 'The Challenge for Democracy'. Journal of Democracy 14 (4): 10114.

Dawson, James. 2016. Cultures of Democracy in Serbia and Bulgaria: How Ideas Shape Publics. Routledge.

Dimitrova, Antoaneta L. 2018. 'The Uncertain Road to Sustainable Democracy: Elite Coalitions, Citizen Protests and the Prospects of Democracy in Central and Eastern Europe'. East European Politics 34 (3): 257-75.

Donskis, Leonidas. 1999. 'Between Identity and Freedom: Mapping Nationalism in Twentieth-Century Lithuania'. East European Politics \& Societies 13: 474-500.

Dryzek, John S. 2000. Deliberative Democracy and Beyond: Liberals, Critics, Contestations. Oxford: Oxford University Press.

Đurašković, Stevo. 2016. 'National Identity-Building and the 'Ustaša-Nostalgia" in Croatia: The Past That Will Not Pass'. Nationalities Papers 0 (0): 1-17.

Ekman, Joakim, Sergiu Gherghina, and Olena Podolian. 2016. 'Challenges and Realities of Political Participation and Civic Engagement in Central and Eastern Europe'. East European Politics 32 (1): 1-11. 
Enyedi, Z., and L. Linek. 2008. 'Searching for the Right Organization: Ideology and Party Structure in East-Central Europe'. Party Politics 14 (4): 455.

Greskovits, Béla. 2015. 'The Hollowing and Backsliding of Democracy in East Central Europe'. Global Policy 6: 28-37.

Guasti, Petra, and Lenka Bustikova. 2019. 'In Europe's Closet: The Rights of Sexual Minorities in the Czech Republic and Slovakia'. East European Politics 0 (0): 1-21. https://doi.org/10.1080/21599165.2019.1705282.

Hale, Henry E. 2014. Patronal Politics: Eurasian Regime Dynamics in Comparative Perspective. Cambridge University Press.

Hanley, Seán, and Allan Sikk. 2016. 'Economy, Corruption or Floating Voters? Explaining the Breakthroughs of Anti-Establishment Reform Parties in Eastern Europe'. Party Politics 22 (4): 522-33.

Hanley, Seán, and Milada Anna Vachudova. 2018. 'Understanding the Illiberal Turn: Democratic Backsliding in the Czech Republic'. East European Politics 34 (3): 27696.

Harris, Erika. 2019. 'Nation before Democracy? Placing the Rise of the Slovak Extreme Right into Context'. East European Politics 35 (4): 538-57. https://doi.org/10.1080/21599165.2019.1667770.

Horvat, Srecko, and Igor Stiks. 2015. Welcome to the Desert of Post-Socialism: Radical Politics after Yugoslavia. Verso Books.

Howard, Marc Morjé. 2003. The Weakness of Civil Society in Post-Communist Europe. Cambridge: Cambridge University Press.

Hurrelmann, Achim. 2015. 'Demoi-Cratic Citizenship in Europe: An Impossible Ideal?' Journal of European Public Policy 22 (1): 19-36.

Huszka, Beáta. 2014. 'Framing National Identity in Independence Campaigns: Secessionist Rhetoric and Ethnic Conflict'. Nationalism and Ethnic Politics 20 (2): 153-73.

Jowitt, Ken. 1993. New World Disorder: The Leninist Extinction. Berkley: University of California Press.

Judis, John B. 2016. The Populist Explosion: How the Great Recession Transformed American and European Politics. Columbia Global Reports New York.

Karolewski, Ireneusz Paweł. 2016. 'Protest and Participation in Post-Transformation Poland: The Case of the Committee for the Defense of Democracy (KOD)'. Communist and Post-Communist Studies 49 (3): 255-67. https://doi.org/10.1016/j.postcomstud.2016.06.003.

Keil, Soeren. 2013. 'Europeanization, State-Building and Democratization in the Western Balkans'. Nationalities Papers 41 (3): 343-53.

Kelemen, R. Daniel, and Michael Blauberger. 2017. 'Introducing the Debate: European Union Safeguards against Member States” Democratic Backsliding'. Journal of European Public Policy 24 (3): 317-20.

Kessel, Stijn van. 2015. Populist Parties in Europe: Agents of Discontent? Springer.

Kitschelt, Herbert, and Steven I. Wilkinson. 2007. Patrons, Clients and Policies: Patterns of Democratic Accountability and Political Competition. Cambridge University Press.

Kochenov, Dimitry, and Eline De Ridder. 2011. 'Democratic Conditionality in Eastern Enlargement: Ambitious Window Dressing'. European Foreign Affairs Review 16 (5): 589-605.

Kolev, Kiril. 2019. 'Weak Pluralism and Shallow Democracy: The Rise of Identity Politics in Bulgaria and Romania'. East European Politics 0 (0): 1-18. https://doi.org/10.1080/21599165.2019.1700954.

Kolstø, Pål, and Hans Olav Melberg. 2002. 'Integration, Alienation, and Conflict in Estonia and Moldova at the Societal Level: A Comparison'. In National Integration and 
Violent Conflict in Post-Soviet Societies: The Cases of Estonia and Moldova, edited by Pål Kolstø. Oxford: Roman and Littlefield.

Kopecký, Petr, and Cas Mudde. 2000. 'What Has Eastern Europe Taught Us about the Democratization Literature (and Vice Versa)?” European Journal of Political Research 37 (4): 517-39.

Kovras, Iosif, and Neophytos Loizides. 2014. 'The Greek Debt Crisis and Southern Europe: Majoritarian Pitfalls?' Comparative Politics 47 (1): 1-20. https://doi.org/10.5129/001041514813623164.

Krastev, Ivan. 2002. 'The Balkans: Democracy without Choices'. Journal of Democracy 13 (3): 39-53

Laitin, David D. 2002. 'Culture and National Identity:'The East'and European Integration'. West European Politics 25 (2): 55-80.

Lees, Charles. 2018. 'The "Alternative for Germany": The Rise of Right-Wing Populism at the Heart of Europe'. Politics 38 (3): 295-310.

Lendvai, Noémi. 2004. 'The Weakest Link? EU Accession and Enlargement: Dialoguing EU and Post-Communist Social Policy'. Journal of European Social Policy 14 (3): 31933.

Lijphart, Arend. 1997. 'Unequal Participation: Democracy's Unresolved Dilemma'. The American Political Science Review 91 (1): 1-14.

Mair, Peter. 2006. 'Ruling the Void: The Hollowing of Western Democracy'. New Left Review 42: 25-51.

March, Luke, and Cas Mudde. 2005. 'What's Left of the Radical Left? The European Radical Left after 1989: Decline and Mutation'. Comparative European Politics 3 (1): 23-49.

March, Luke. 2017. 'Left and Right Populism Compared: The British Case'. The British Journal of Politics and International Relations 19 (2): 282-303.

McGann, Anthony J., and Herbert Kitschelt. 2005. 'The Radical Right in the Alps: Evolution of Support for the Swiss SVP and Austrian FPÖ'. Party Politics 11 (2): 147-71.

Mikkel, Evald, and Geoffrey Pridham. 2004. 'Clinching the 'Return to Europe": The Referendums on EU Accession in Estonia and Latvia'. West European Politics 27 (4): 716-48.

Minkenberg, Michael. 2002. 'The Radical Right in Postsocialist Central and Eastern Europe: Comparative Observations and Interpretations'. East European Politics \& Societies $16(2): 335-62$.

Minkenberg, Michael. 2013. 'From Pariah to Policy-Maker? The Radical Right in Europe, West and East: Between Margin and Mainstream'. Journal of Contemporary European Studies 21 (1): 5-24.

Mishler, William, and Richard Rose. 1999. 'Five Years After the Fall: Trajectories of Support for Democracy in Post-Communist Europe'. In Critical Citizens: Global Support for Democratic Governance, edited by Norris Pippa, 78-99. Oxford: Oxford University Press.

Morlino, Leonardo, and Mario Quaranta. 2016. 'What Is the Impact of the Economic Crisis on Democracy? Evidence from Europe'. International Political Science Review 37 (5): 618-33.

Mudde, Cas. 2009. Populist Radical Right Parties in Europe. Cambridge University Press Cambridge.

Müller, Jan-Werner. 2016. What Is Populism. Philadelphia: University of Pennsylvania Press.

Nordensvard, Johan, and Markus Ketola. 2014. 'Nationalist Reframing of the Finnish and Swedish Welfare States - The Nexus of Nationalism and Social Policy in Far-Right Populist Parties'. Social Policy \& Administration, August, n/a-n/a. https://doi.org/10.1111/spol.12095. 
Noutcheva, Gergana. 2016. 'Societal Empowerment and Europeanization: Revisiting the EU's Impact on Democratization'. JCMS: Journal of Common Market Studies 54 (3): 691-708. https://doi.org/10.1111/jcms.12322.

Offe, Claus. 1991. 'Capitalism by Democratic Design? Democratic Theory Facing the Triple Transition in East Central Europe'. Social Research 58 (4): 865-82.

Orenstein, Mitchell A. 2009. 'What Happened in East European (Political) Economies?: A Balance Sheet for Neoliberal Reform'. East European Politics and Societies 23 (4): 479-90.

Pappas, Takis S. 2016. 'Modern Populism: Research Advances, Conceptual and Methodological Pitfalls, and the Minimal Definition'. In Oxford Research Encyclopedia of Politics.

Petsinis, Vassilis. 2019. 'Ethnopolitics in Central and Eastern Europe in a State of Flux'. Ethnopolitics, 1-4.

Petsinis, Vassilis. 2019. 'Identity Politics and Right-Wing Populism in Estonia: The Case of EKRE'. Nationalism and Ethnic Politics 25 (2): 211-30.

Pirro, Andrea LP, and Stijn Van Kessel. 2017. 'United in Opposition? The Populist Radical Right's EU-Pessimism in Times of Crisis'. Journal of European Integration 39 (4): 405-20.

Pirro, Andrea LP. 2014. 'Populist Radical Right Parties in Central and Eastern Europe: The Different Context and Issues of the Prophets of the Patria'. Government and Opposition 49 (4): 600-629.

Pirro, Andrea LP. 2015. The Populist Radical Right in Central and Eastern Europe: Ideology, Impact, and Electoral Performance. Routledge.

Plattner, Marc F., and Larry Jay Diamond. 2007. 'Is East-Central Europe Backsliding?" Journal of Democracy 18 (4): 5-6.

Pridham, Geoffrey. 2002. 'EU Enlargement and Consolidating Democracy in PostCommunist States - Formality and Reality'. Journal of Common Market Studies 40 (3): 953-73.

Rohrschneider, Robert. 2002. 'The Democracy Deficit and Mass Support for an EU-Wide Government'. American Journal of Political Science, 463-75.

Rooduijn, Matthijs, and Teun Pauwels. 2011. 'Measuring Populism: Comparing Two Methods of Content Analysis'. West European Politics 34 (6): 1272-83.

Rose, Richard, and Neil Munro. 2003. Elections and Parties in New European Democracies. cq Press Washington, DC.

Rose, Richard, William Mishler, and Christian Haerpfer. 1998. Democracy and Its Alternatives: Understanding Post-Communist Societies. Baltimore, Maryland: The John Hopkins University Press.

Rueschemeyer, Dietrich, Marilyn Rueschemeyer, and Bjorn Wittrock. 1998. Participation and Democracy, East and West: Comparisons and Interpretations. Armonk, NY: M.E.Sharp.

Rueschemeyer, Dietrich. 2015. Participation and Democracy East and West: Comparisons and Interpretations: Comparisons and Interpretations. Routledge.

Rupnik, Jacques. 2007. 'From Democracy Fatigue to Populist Backlash'. Journal of Democracy 18 (4): 17-25.

Sandel, Michael J. 2018. 'Populism, Liberalism, and Democracy'. Philosophy \& Social Criticism 44 (4): 353-59.

Sata, Robert, and Ireneusz Pawel Karolewski. 2019. 'Caesarean Politics in Hungary and Poland'. East European Politics 0 (0): 1-20. https://doi.org/10.1080/21599165.2019.1703694. 
Schimmelfennig, Frank, Stefan Engert, and Heiko Knobel. 2006. International Socialization in Europe: European Organizations, Political Conditionality and Democratic Change. Palgrave Macmillan.

Schwellnus, Guido. 2006. 'Reasons for Constitutionalization: Non-Discrimination, Minority Rights and Social Rights in the Convention on the EU Charter of Fundamental Rights'. Journal of European Public Policy 13 (8): 1265-83.

Scicluna, Nicole, and Stefan Auer. 2019. 'From the Rule of Law to the Rule of Rules: Technocracy and the Crisis of EU Governance'. West European Politics 0 (0): 1-23. https://doi.org/10.1080/01402382.2019.1584843.

Sedelmeier, Ulrich. 2017. 'Political Safeguards against Democratic Backsliding in the EU: The Limits of Material Sanctions and the Scope of Social Pressure'. Journal of European Public Policy 24 (3): 337-51.

Shapiro, Ian. 2003. The State of Democratic Theory. Princeton University Press.

Shaw, Jo, and Antje Wiener. 2000. 'The Paradox of the European Polity'. The State of the European Union 5: 64-88.

Sikk, Allan. 2006. 'From Private Organizations to Democratic Infrastructure: Political Parties and the State in Estonia'. Journal of Communist Studies and Transition Politics 22 (3): $341-61$.

Stroschein, Sherrill. 2019. 'Populism, Nationalism, and Party Politics'. Nationalities Papers, $1-13$.

Tismaneanu, Vladimer. 2002. 'Discomforts of Victory: Democracy, Liberal Values and Nationalism in Post-Communist Europe'. West European Politics 25 (2): 81-100.

Urbinati, Nadia. 2014. Democracy Disfigured. Harvard University Press.

Usherwood, Simon. 2019. 'Shooting the Fox? UKIP's Populism in the Post-Brexit Era'. West European Politics, 1-21.

Vachudova, Milada A, and Liesbet Hooghe. 2009. 'Postcommunist Politics in a Magnetic Field: How Transition and EU Accession Structure Party Competition on European Integration'. Comparative European Politics 7 (2): 179-212.

Wimmer, Andreas. 2008. 'Elementary Strategies of Ethnic Boundary Making'. Ethnic and Racial Studies 31 (6): 1025-55. https://doi.org/10.1080/01419870801905612. 